\title{
SINTESIS ZEOLIT SILIKALIT-1 MENGGUNAKAN LIMBAH TONGKOL JAGUNG SEBAGAI SUMBER SILIKA
}

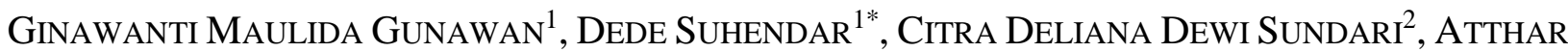 \\ LUQMAN IVANSYAH $^{3}$, SONI SETIADJI ${ }^{1}$,DAN YUSUF ROHMATULLOH ${ }^{1}$ \\ ${ }^{1}$ Jurusan Kimia, Fakultas Sains dan Teknologi, UIN Sunan Gunung Djati Bandung, \\ Jl. A. H. Nasution No. 105 Cibiru Kota Bandung
}

${ }^{2}$ Program Studi Pendidikan Kimia, Fakultas Tarbiyah dan Keguruan, UIN Sunan Gunung Djati Bandung, Jl. A. H. Nasution No. 105 Cibiru Kota Bandung

${ }^{3}$ Program Studi Magister Sains Komputasi, Fakultas Matematika dan Ilmu Pengetahuan Alam, Institut Teknologi Bandung

Jl. Ganesha No. 1 Lb. Siliwangi, Coblong, Kota Bandung

*alamat email korespondensi: dede.suhendar@uinsgd.ac.id

\begin{tabular}{|c|c|}
\hline Informasi Artikel & Abstrak/Abstract \\
\hline $\begin{array}{l}\text { Riwayat Naskah : } \\
\text { Diterima pada } 24 \\
\text { November } 2017 \\
\text { Diterima setelah } \\
\text { direvisi pada } 27 \\
\text { Desember } 2017 \\
\text { Diterbitkan pada } 29 \\
\text { Desember } 2017\end{array}$ & $\begin{array}{l}\text { Tongkol jagung merupakan limbah agrikultural yang banyak mengandung silika yang } \\
\text { pemanfaatannya belum maksimal. Silika dai tongkol jagung dapat menjadi solusi alternatif } \\
\text { untuk menggantikan sumber silika komersial. Penelitian ini bertujuan untuk mengisolasi, } \\
\text { mensintesis, dan mengkarakterisasi zeolit silikalit-1 dari limbah tongkol jagung. Metode sol- } \\
\text { gel digunakan untuk mengisolasi silika yang selanjutnya digunakan untuk sintesis zeolit } \\
\text { silikalit-1 dengan metode hidrotermal. Komposisi silika ditentukan oleh X-Ray Fluorescence } \\
(X R F) \text {. Silika yang dihasilkan sebesar } 34,55 \% \text {. Pengotor utama silika yang dihasilkan dari } \\
\text { hasil ekstraksi adalah } \mathrm{Na}_{2} \mathrm{O} \text { sebesar } 7,48 \% \text {. X-Ray Diffraction (XRD) menunjukkan bahwa } \\
\text { silika hasil isolasi adalah amorf. Data Fourier Transform InfraRed (FTIR) menunjukkan } \\
\text { adanya siloksan dan kelompok silanol didalam silika. X-Ray Diffraction (XRD) menunjukan } \\
\text { bahwa zeolit silikalit-1 telah berhasil disintesis dengan ukuran kristal sebesar } 15,28 \text { nm. Data }\end{array}$ \\
\hline $\begin{array}{l}\text { Kata Kunci: Tongkol } \\
\text { jagung; silika; sol- } \\
\text { gel; hidrotermal; } \\
\text { silikalit-1. }\end{array}$ & $\begin{array}{l}\text { Fourier Transform InfraRed (FTIR) menunjukkan adanya gugus D5R pentasil pada zeolit } \\
\text { yang dihasilkan. Scanning Electron Microscope (SEM) menunjukan morfologi dari zeolit } \\
\text { silikalit-1 berbentuk bola-bola kecil yang merupakan benih kristal heksagonal yang } \\
\text { sepenuhnya belum terbentuk. }\end{array}$ \\
\hline
\end{tabular}

Keywords: Corn cob; Corn cobs are a lot of silica-containing agricultural waste which has not been maximized. silica; sol-gel; hydrothermal; silicalite-1. \begin{abstract}
Silica from corn cobs can be an alternative solution to replace commercial silica sources. This study aims to isolate, synthesize, and characterize silicalite-1 zeolite from corn cobs waste. Sol-gel method is used to isolate the silica which is then used for the synthesis of zeolites silicalite-1 with the hydrothermal method. Silica composition is determined by the XRay Fluorescence (XRF). Silica produced by 34.55\%. Main impurities of silica resulting from the extraction is Na2O of 7.48\%. X-ray Diffraction (XRD) showed that the isolated silica is amorphous. Data Fourier Transform Infrared (FTIR) showed a siloxane and silanol groups in silica. X-ray Diffraction (XRD) showed that the zeolite silicalite-1 has been successfully synthesized with a crystal size of 15,28 $\mathrm{nm}$. Data Fourier Transform Infrared (FTIR) showed a group D5R Pentasil zeolites produced. Scanning Electron Microscope (SEM) shows the morphology of the zeolite silicalite-1 in the form of small balls which is a hexagonal crystal seed is not fully formed.
\end{abstract}

\section{PENDAHULUAN}

Indonesia merupakan salah satu negara yang kaya akan sumber daya alam yang melimpah. Hal ini terbukti dengan keadaan tanah Indonesia yang sangat subur. Negara Indonesia memiliki peran penting sebagai produsen bahan pangan di mata dunia, khususnya sebagai produsen Jagung. Jagung merupakan sumber daya alam yang dapat diperbaharui dimana keberadaannya sangat melimpah di Indonesia sebagai negara agraris [1]. Berdasarkan data perhitungan dari Badan Pusat Statistik pada tahun 2013, diketahui bahwa paling tidak sebanyak 13.811.642 Ton tongkol jagung akan menjadi limbah. Jagung merupakan tumbuhan yang memiliki banyak manfaat, antara lain sebagai makanan pokok di sebagian wilayah yang ada di Indonesia, sebagai bahan baku utama pembuatan tepung maizena, minyak dan lain-lain [2]. Namun, dari $100 \mathrm{~kg}$ jagung yang termanfaatkan, 
dihasilkan limbah tongkol jagung sebanyak $18 \mathrm{~kg}$ yang belum termanfaatkan dengan maksimal.

Di sisi lain, kandungan senyawa kimia pada tongkol jagung secara umum antara lain selulosa, hemiselulosa, lignin, dan silika [2], yang mana silika pada tongkol jagung dapat diisolasi dan diolah lebih lanjut untuk meningkatkan nilai guna tongkol jagung, salah satunya adalah dengan memanfaatkan silika dari tongkol jagung untuk sintesis zeolit. Zeolit adalah aluminosilikat terhidrasi dari alkali dan alkali tanah. Sekitar 40 zeolit alam telah diidentifikasi selama 200 tahun terakhir; yang paling umum adalah analcime, chabazite [3], clinoptilolite [4], erionite [5], ferrierite [6], heulandite [7], mordenite [8], dan phillipsit [9]. Varietas yang paling umum ditambang dari zeolit alam chabazite dan klinoptilolit [10]. Lebih dari 150 zeolit telah disintesis; yang paling umum adalah zeolit A, zeolit X [11], zeolit Y [12], dan ZMS-5 [13] karena sifat-sifat adsorpsi zeolit tersebut unik untuk aplikasi katalis, pertukaran ion, dan sifat saringan molekuler [14]. ZSM-5 merupakan keluarga dari zeolit dengan jenis struktur MFI dan salah satu jenis zeolit yang pertama kali dibuat oleh divisi katalis Mobil Oil Corporation pada tahun 1972 [13]. ZSM-5 mempunyai sifat fisik dan kimia sangat dipengaruhi oleh berbagai keadaan antara lain faktor kisi dan faktor pori. ZSM-5 adalah zeolit dengan perbandingan $\mathrm{Si}$ lebih banyak dari pada $\mathrm{Al}$, atau dapat dikatakan merupakan zeolit yang kaya akan Si, zeolit ZSM-5 mempunyai sifat sangat hidrofobik, menyerap molekul yang tidak polar atau berinteraksi lemah dalam air dan molekul yang sangat polar serta baik digunakan sebagai katalisator untuk hidrokarbon. Sedangkan zeolit Silikalit-1 adalah jenis zeolit ZSM-5 namun tanpa mengandung Al sama sekali atau dapat dikatakan tidak mempunyai sisi kation sama sekali. Zeolit silikalit-1 sangat hidrofobik sehingga dapat mengeluarkan atau memisahkan suatu molekul organik dari suatu campuran air [15].

Pada umumnya, sintesis zeolit menggunakan sumber silika komersial seperti Ludox dan TEOS dengan metode hidrothermal menggunakan suhu tinggi. Ditinjau dari segi nilai ekonomi, sintesis zeolit yang menggunakan bahan komersial tersebut membutuhkan biaya yang relatif mahal sehingga diperlukan suatu alternatif untuk mengganti sumber silika komersial tersebut dengan bahan yang mudah didapat dan memiliki harga yang relatif lebih murah. Salah satu solusi alternatif untuk menggantikan silika komersial tersebut adalah dengan menggunakan silika dari limbah agrikultural seperti sekam padi, ampas tebu, daun bambu, dan tongkol jagung. Vaibhav $d k k$ telah berhasil mengisolasi silika dari sekam padi dan daun bambu [16], dan Velmurugan $d k k$ telah berhasil mengisolasi silika dari limbah tongkol jagung dengan menggunakan metode solgel [17]. Namun, sampai saat ini belum ada peneliti yang menggunakan silika dari limbah tongkol jagung sebagai sumber silika untuk sintesis zeolit Silikalit-1.

Penelitian ini dilakukan sintesis zeolit silikalit-1 menggunakan limbah tongkol jagung sebagai sumber silika. Sintesis zeolit silikalit-1 menggunakan limbah tongkol jagung sebagai sumber silika dilakukan dengan menggunakan metode hidrotermal.

\section{EKSPERIMEN}

Sintesis zeolit silikalit-1 dilakukan dengan menggunakan metode hidrotermal, yang mana silika yang diperlukan merupakan hasil isolasi dari limbah tongkol jagung. Dalam sintesis zeolitsilikalit-1, digunakan pula TPABr sebagai SDA untuk pengarah struktur zeolit silikalit-1.

\section{Material}

Bahan-bahan yang akan digunakan dalam penelitian ini adalah tongkol jagung, $\mathrm{NaOH}$ (p.a), TPABr, dan akua DM.

\section{Instrumentasi}

Karakterisasi silika dan zeolit silikalit-1 digunakan X-Ray Fluorescence (XRF), X-Ray Diffraction (XRD) Philips PW 1835, Fourier Transform InfraRed (FTIR) Spectroscopy Cary 600, dan Scanning Elektron Microscopy-Energy Dispersive X-Ray (SEM-EDX) Jeol JCM-6000.

\section{Prosedur}

\section{Preparasi Sampel}

Limbah tongkol jagung dicuci sampai bersih, dikeringkan dan dipotong sampai ukuran \pm $2 \mathrm{~cm}$, kemudian dikalsinasi pada suhu $650^{\circ} \mathrm{C}$ selama 5 jam. Abu hasil kalsinasi kemudian ditambah dengan larutan $\mathrm{NaOH}$ untuk mengisolasi silika. Silika hasil kalsinasi kemudian disentesis menjadi zeolit Silikalit-1 di dalam autoclave selama 24 jam dengan suhu $180^{\circ} \mathrm{C}$.

\section{Isolasi Silika dari Tongkol Jagung}

Abu tongkol jagung hasil pembakaran, selanjutnya dilarutkan ke dalam 1 M larutan $\mathrm{NaOH}$ dan dipanaskan pada suhu $85^{\circ} \mathrm{C}$ disertai pengadukan selama 1 jam untuk melarutkan silika 
yang terdapat dalam abu tongkol jagung dalam bentuk larutan natrium silikat. Selanjutnya, larutan natrium silikat disaring menggunakan penyaring buchner. Perolehan silika dari larutan natrium silikat dilakukan dengan menambahkan $3 \mathrm{M}$ larutan asam sulfat sampai $\mathrm{pH}$ larutan mencapai pH 7 dan kemudian larutan $\mathrm{pH} 7$ tersebut dibiarkan (di-aging) selama 24 jam. Endapan silika yang dihasilkan dicuci dengan air panas secara berulang dan dikeringkan di oven pada suhu $110^{\circ} \mathrm{C}$ selama $12 \mathrm{jam}$. Selanjutnya, endapan silika tersebut dikarakterisasi dengan XRF untuk mengetahui komposisi $\mathrm{SiO}_{2}$ pada sampel silika tersebut dan XRD untuk mengetahui derajat kristalinitas padatan $\mathrm{SiO}_{2}$ yang dihasilkan. Akhirnya, $\mathrm{SiO}_{2}$ hasil isolasi digunakan sebagai sumber silika untuk sintesis zeolit Silikalit-1.

\section{Sintesis Zeolit Silikat-1 menggunakan Metode Hidrotermal}

Silika hasil isolasi ditimbang sebanyak 1,65 $\mathrm{g}$, kemudian dilarutkan dalam $17,5 \mathrm{~mL}$ larutan $\mathrm{NaOH}$, larutan ini disebut campuran A. TPABr ditimbang sebanyak 2,76 g, kemudian dilarutkan dalam 17,5 mL larutan $\mathrm{NaOH}$, campuran ini desebut campuran B. Kemudian campuran B dituangkan ke dalam campuran A sehingga diperoleh campuran $\mathrm{C}$ dengan perbandingan $\mathrm{aSiO}_{2}$ : bTPABr : cNaOH: dH2O, dimana nilai a, b, c, dan d adalah $1: 0,7: 1,14: 141,92$. Campuran C kemudian diaduk menggunakan pengaduk magnetik selama 2 jam. Selanjutnya, campuran C hasil pengadukan selama 2 jam tersebut dimasukkan ke dalam autoclave dan dipanaskan di dalam oven pada suhu $180^{\circ} \mathrm{C}$ selama 24 jam. Setelah 24 jam, autoclave dikeluarkan dari oven dan didinginkan sampai suhu ruang. Selanjutnya, larutan hasil sintesis disaring menggunakan penyaring buchner. Padatan yang diperoleh di kertas saring kemudian dicuci menggunakan akua DM beberapa kali. Kemudian, padatan tersebut dikeringkan dalam oven pada temperatur $110^{\circ} \mathrm{C}$ selama 24 jam. Selanjutnya, padatan dikalsinasi pada temperatur $600^{\circ} \mathrm{C}$ selama 5 jam untuk menghilangkan $\mathrm{TPABr}$ dan pengotor-pengotor organik lainnya. Selanjutnya, zeolit Silikalit-1 dikarakterisasi menggunakan XRD untuk mengkonfirmasi tipe zeolit yang terbentuk; SEM untuk melihat morfologi Silikalit-1 yang terbentuk; dan FT-IR untuk mengkonfirmasi mode vibrasi pada Silikalit-1. Sub-bab untuk prosedur jika terdiri dari beberapa perlakuan atau metode.

\section{HASIL DAN PEMBAHASAN}

\section{Hasil Analisis Silika dari Tongkol Jagung dengan XRF}

Isolasi silika dari limbah tongkol jagung dilakukan dengan metode sol-gel seperti yang telah dilakukan oleh Velmurugan $d k k$. Silika hasil isolasi dianalisis dengan XRF untuk mengetahui persentase kemurnian $\mathrm{SiO}_{2}$ dan unsur-unsur serta senyawa yang terkandung di dalamnya. Dari hasil analisis menggunakan XRF, diketahui silika hasil isolasi mempunyai tingkat kemurnian sebesar $50,1 \%$. Akan tetapi kandungan silika hasil sintesis dari tongkol jagung yang didapat pada penelitian ini berbeda bila dibandingkan dengan penelitian sebelumnya, dimana kandungan silika dari hasil sintesis tongkol jagung adalah $60,20 \%$ [17]. Hal ini disebabkan karena tongkol jagung yang digunakan sebagai sampel mempunyai jenis yang berbeda disetiap daerah. Silika yang terdapat pada tongkol jagung berasal dari tanah dimana tanaman jagung tersebut ditaman sehingga persentase silika dari tongkol jagung satu dengan yang lainnya pasti akan berbeda disetiap daerah tergantung dari tanaman jagung tersebut ditanam, dan disebabkan karena masih terkandung pengotor berupa $\mathrm{Na}_{2} \mathrm{O}$ yang disebabkan karena pencucian silika dengan akua DM panas selama proses isolasi kurang banyak, yang mana unsur natrium $(\mathrm{Na})$ tersebut berasal dari penambahan natrium hidroksida $(\mathrm{NaOH})$ untuk memperoleh natrium silikat $\left(\mathrm{Na}_{2} \mathrm{SiO}_{3}\right)$ pada proses isolasi silika tongkol jagung dengan reaksi sebagai berikut:

$\mathrm{SiO}_{2(s)}+2 \mathrm{NaOH}_{(a q)} \rightarrow \mathrm{Na}_{2} \mathrm{SiO}_{3(l)}+\mathrm{H}_{2} \mathrm{O}_{(l)}$

$\mathrm{Na}_{2} \mathrm{SiO}_{3}$ yang dihasilkan pada reaksi diatas selanjutnya bereaksi dengan $\mathrm{H}_{2} \mathrm{SO}_{4}$ dan menghasilkan endapan $\mathrm{SiO}_{2}$ sesuai dengan reaksi sebagai berikut :

$\mathrm{Na}_{2} \mathrm{SiO}_{3(l)}+\mathrm{H}_{2} \mathrm{SO}_{4(a q)} \rightarrow \mathrm{SiO}_{2(s)}+\mathrm{Na}_{2} \mathrm{SO}_{4(l)}+\mathrm{H}_{2} \mathrm{O}_{(l)}$

Penambahan $\mathrm{H}_{2} \mathrm{SO}_{4}$ bertujuan untuk memberikan suasana asam, karena $\mathrm{SiO}_{2}$ baru akan terbentuk pada kondisi $\mathrm{pH}<10$ [18]. Dari hasil reaksi tersebut didapatkan produk berupa garam natrium sulfat $\left(\mathrm{Na}_{2} \mathrm{SO}_{4}\right)$ yang dapat hilang dengan proses pelarutan menggunakan air. Semakin sering proses pencucian dilakukan maka akan diperoleh silika murni sebagai produk hasil sintesis silika tongkol jagung [16].

Selain menggunakan $\mathrm{H}_{2} \mathrm{SO}_{4}, \mathrm{HCl}$ juga dapat digunakan sebagai asam untuk mengendapkan silika seperti pada reaksi berikut:

$\mathrm{Na}_{2} \mathrm{SiO}_{3(l)}+2 \mathrm{HCl}_{(a q)} \rightarrow \mathrm{SiO}_{2(s)}+2 \mathrm{NaCl}_{(l)}+\mathrm{H}_{2} \mathrm{O}_{(l)}$ 
Dari hasil reaksi tersebut, didapatkan produk berupa $\mathrm{NaCl}$ yang dapat hilang dengan proses pelarutan menggunakan air. Penambahan $\mathrm{HCl}$ pada proses pembentukan silika gel akan menyebabkan reaksi kondensasi terhadap ion silikat serta menyebabkan terjadinya protonasi gugus siloksi (Si-O) menjadi silanol ( $\mathrm{Si}-\mathrm{OH})$ [19].

\section{Hasil Analisis Silika dengan FT-IR}

Penggunaan spektroskopi FT-IR bertujuan untuk mengetahui gugus fungsional suatu senyawa, selain itu, bisa juga digunakan untuk mengidentifikasi senyawa dan menentukan struktur molekul. Pada silika hasil isolasi dari limbah tongkol jagung terdapat beberapa vibrasi gugus seperti yang ditunjukkan oleh Gambar 1 yang memperlihatkan hasil analisi FT-IR dari silika tongkol jagung.

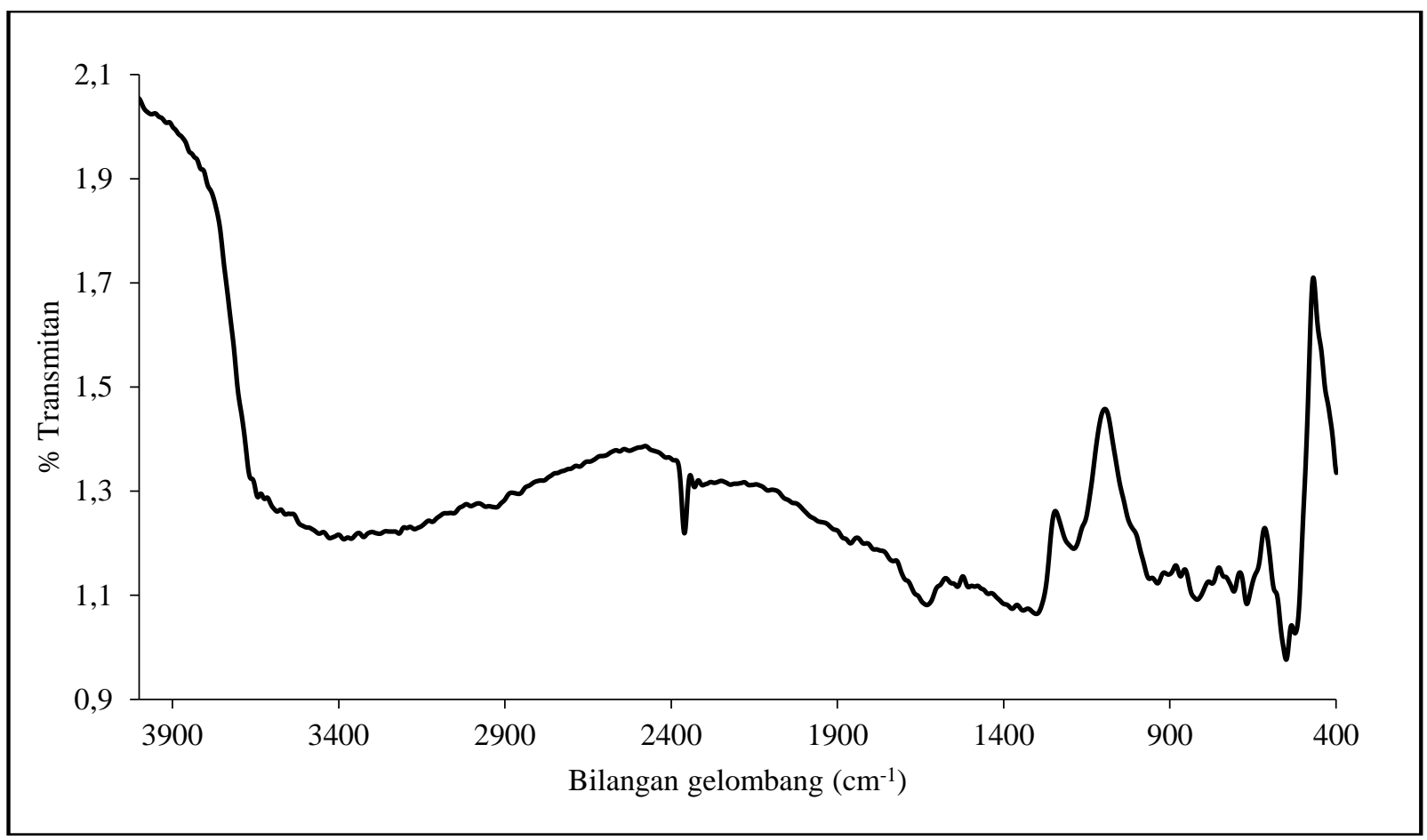

Gambar 1. SpektraFT-IR silika hasil sintesis tongkol jagung

Dari Gambar 1 diperoleh beberapa gugus yang dapat dilihat pada Tabel 1.

Tabel 1. Spektrum hasil FTIR silika tongkol jagung

\begin{tabular}{ccc}
\hline $\begin{array}{c}\text { Bilangan } \\
\text { gelombang } \\
\left(\mathrm{cm}^{-1}\right)\end{array}$ & $\begin{array}{c}\text { Bilangan } \\
\text { gelombang } \\
\text { referensi }\left(\mathrm{cm}^{-1}\right)\end{array}$ & Gugus Fungsi \\
\hline 550,043 & $400-600$ & $\mathrm{Si}-\mathrm{O}-\mathrm{Si}$ \\
668,259 & $620-900$ & $\mathrm{Si}-\mathrm{OH}$ \\
1189,062 & $1100-1200$ & $\mathrm{Si}-\mathrm{O}-\mathrm{Si}$ \\
3458,256 & $3500-3600$ & O-H \\
\hline
\end{tabular}

Pola serapan dari silika hasil sintesis pada Gambar 1 menunjukkan bahwa serapan dengan pita lebar pada daerah bilangan gelombang $3458,256 \mathrm{~cm}^{-1}$ merupakan pita serapan dari vibrasi gugus hidroksi $-\mathrm{OH}$ pada gugus silanol ( $\mathrm{Si}-\mathrm{OH})$. Pita serapan di daerah 1189,062 $\mathrm{cm}^{-1}$ merupakan pita serapan dari vibrasi ulur asimetri dari gugus $\mathrm{Si}-\mathrm{O}$ pada gugus siloksan ( $\mathrm{Si}-\mathrm{O}-\mathrm{Si})$. Serapan pada bilangan gelombang $668,259 \mathrm{~cm}^{-1}$ menunjukkan adanya vibrasi tekuk dari gugus - $\mathrm{OH}$ pada silanol (Si-OH), dan vibrasi tekuk gugus siloksan (Si-O$\mathrm{Si}$ ) ditunjukkan dengan pita serapan pada bilangan gelombang 550,043 $\mathrm{cm}^{-1}$. Dari data tersebut kita dapat mengetahui bahwa secara umum pita serapan yang muncul pada spektra silika hasil sintesis adalah gugus silanol $(\mathrm{Si}-\mathrm{OH})$ dan gugus siloksan (Si-O-Si) [17].

\section{Hasil Analisis Silika dengan XRD}

Analisis kualitatif difraksi sinar-X bertujuan untuk mengkonfirmasi senyawa yang telah terbentuk adalah silika $\left(\mathrm{SiO}_{2}\right)$ atau bukan. Dari hasil analisis pola difraksi sinar-X dapat dilihat struktur dan fase kristal yang terdapat pada silika. Silika sendiri memiliki beberapa fase, diantaranya yaitu amorf dan kristal tergantung pada temperatur pengabuan [20]. Dari hasil analisis pola difraksi sinar-X dapat dilihat struktur dan fase kristal yang terdapat pada silika tongkol jagung.

Pada Gambar 2 terlihat bahwa silika dari tongkol jagung telah berhasil diisolasi. Namun, dari pola difraksi yang dihasilkan terlihat bahwa hasil sintesis silika tongkol jagung masih banyak terdapat pengotor, hal ini dibuktikan dengan masih terdapatnya puncak-puncak pola difraksi yang 
tidak diinginkan. Puncak pola difraksi pada rentang $2 \theta$ 30-40 menunjukan pola difraksi dalam bentuk kuarsa. Adanya bentuk kuarsa dikarenakan ketika penambahan asam, $\mathrm{pH}$ larutan masih dalam suasana basa [21]. Selain itu, masih terdapatnya pengotor ini disebabkan karena proses pencucian silika selama proses sintesis dan pencucian setelah terbentuk silika gel perlu dilakukan lebih banyak lagi. Di sisi lain, fasa kristal dalam silika tongkol jagung sangat bergantung pada temperatur pengabuan, pada umumnya silika yang disintesis dari abu tongkol jagung terdapat dalam bentuk amorf dan akan tetap dalam keadaan tersebut apabila proses pengabuan tongkol jagung pada temperatur $500-700^{\circ} \mathrm{C}$.

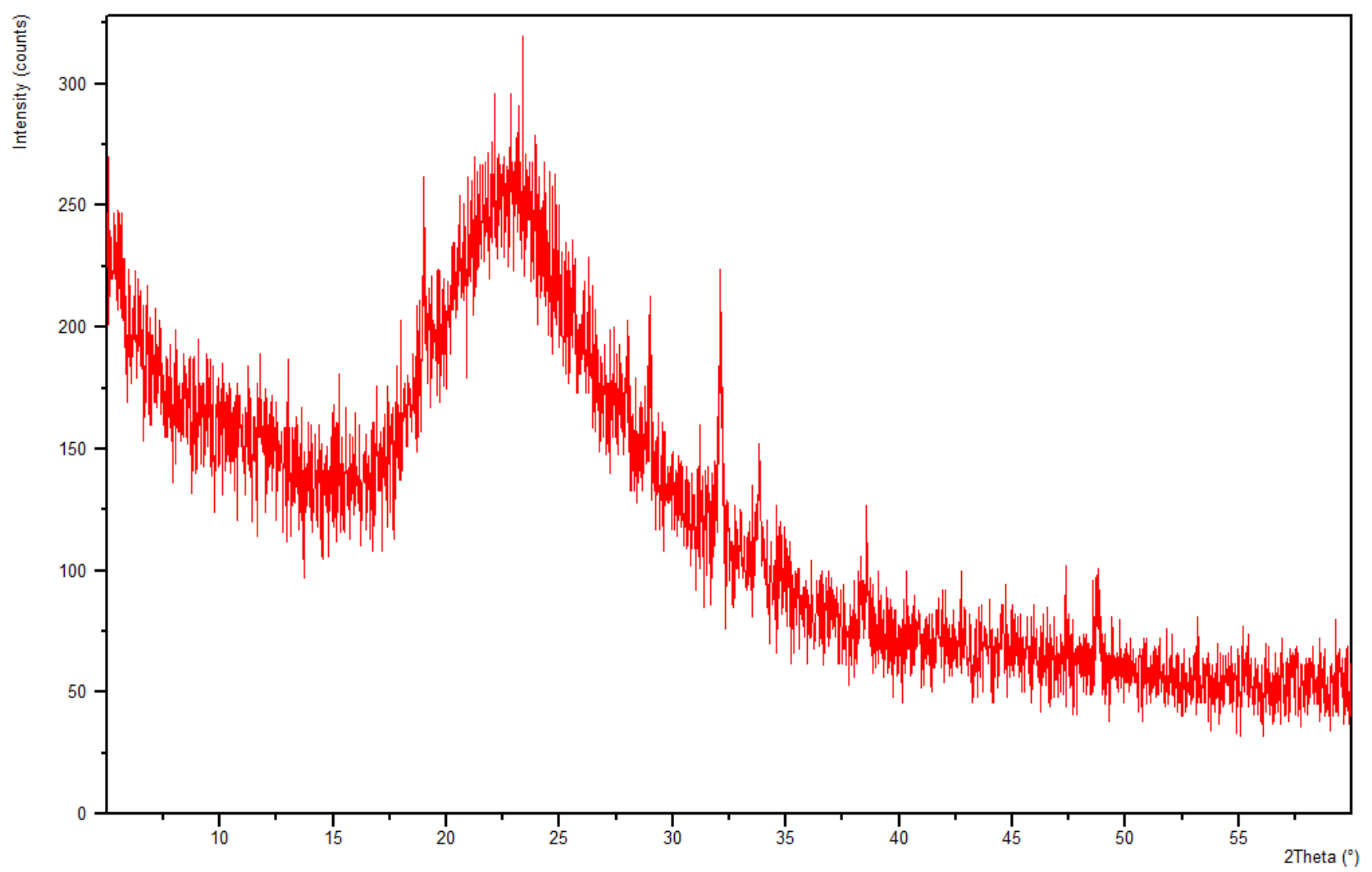

Gambar 2. Difraktogram silika tongkol jagung

Hasil karakterisasi silika tongkol jagung menggunakan XRD menunjukan silika hasil isolasi dari togkol jagung dalam bentuk amorf, seperti yang dijelaskan oleh Velmurugan $d k k$. Difraksi puncak pada $2 \theta=23,5$ menegaskan pembentukan silika amorf [17]. Dari hasil tersebut setelah dibandingkan dengan Joint Committee on Powder Diffraction Standards (JCPDS) puncak $2 \theta$ yang dihasilkan pada penelitian ini menunjukan adanya kesesuaian puncak khas silika yaitu pada $2 \theta=23,5$ sehingga silika yang dihasilkan dari tongkol jagung adalah silika amorf. Terbentuknya silika dalam bentuk amorf dikarenakan pada penelitian ini dilakukan proses pengabuan pada suhu $650^{\circ} \mathrm{C}$ [17].

\section{Hasil Analisis Zeolit dengan XRD}

Hasil karakterisasi difraksi sinar-X zeolit silikalit-1 dengan suhu inkubasi $180^{\circ} \mathrm{C}$ selama 24 jam menghasilkan puncak khas $2 \theta$ pada $7,61^{\circ}$, $8,53^{\circ}, 22,76^{\circ}, 23,64^{\circ}, 24,08^{\circ}, 25,56^{\circ}, 26,51^{\circ}$, $28,97^{\circ}, 29,65^{\circ}, 44,74^{\circ}, 46,16^{\circ}$ dan puncak tinggi yang tajam pada $7,61^{\circ}, 8,53^{\circ}$, dan $22,76^{\circ}$ seperti yang ditunjukkan Gambar 3.

Hasil karakterisasi menggunakan XRD menunjukkan padatan hasil sintesis pada sampel mengindikasikan terbentuknya struktur zeolit, karena adanya kesesuaian pola difraktogram dengan penelitian sebelumnya yang telah dilakukan oleh Chelsey Anderson $d k k$ [22]. Rasio mol zeolit silikalit-1 adalah $\mathrm{SiO}_{2}:$ TPABr $: \mathrm{NaOH}$ : $\mathrm{H}_{2} \mathrm{O}$ sebesar $1: 0,7: 1,14: 141,92$ dengan memperhitungkan kemurnian $\mathrm{SiO}_{2}$ sebesar $50,1 \%$. Dalam sintesis zeolit silikalit-1 rasio mol yang digunakan memiliki perbedaan rasio mol dengan penelitian sebelumnya. Walaupun terdapat perbedaan rasio mol, namun zeolit silikalit-1 dapat terbentuk. Hal tersebut dikarenakan untuk sintesis zeolit khususnya zeolit silikalit-1 dengan menggunakan TPABr sebagai pengarah struktur, tidak diperlukan perbandingan rasio antara 
$\mathrm{Si} / \mathrm{TPABr}$ yang tepat atau dapat dikatakan rasio rasio seperti yang ditunjukkan oleh Tabel 2. $\mathrm{Si} / \mathrm{TPABr}$ dapat digunakan dalam beberapa variasi

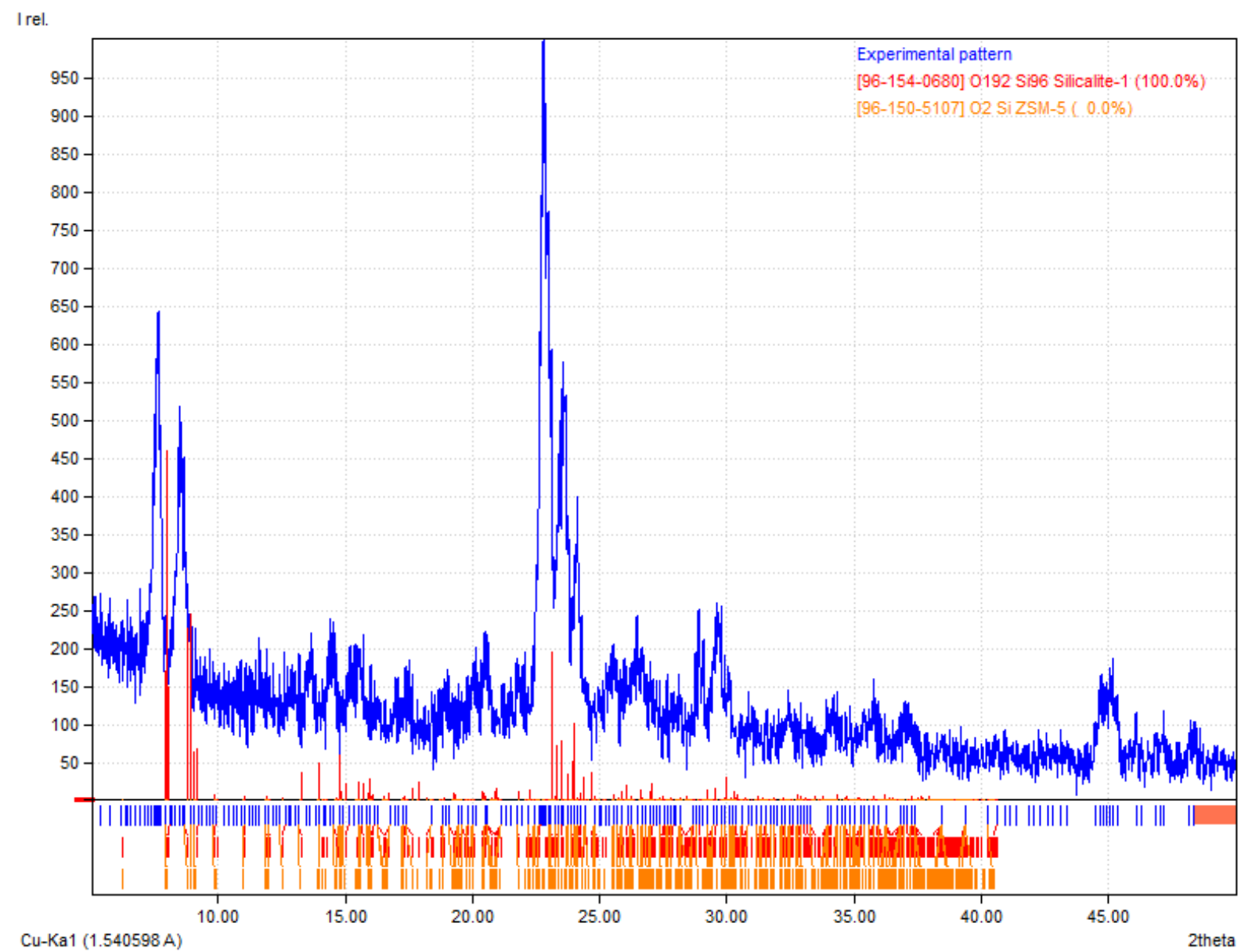

Gambar 1. Difraktogram Zeolit Silikalit-1

Tabel 1. Perbandingan rasio antara $\mathrm{Si} / \mathrm{TPABr}$ pada beberapa penelitian

\begin{tabular}{cccc}
\hline Penelitian & $\mathrm{SiO}_{2}$ & TPABr & Tipe Zeolit \\
\hline Christopher M. Lew & 3 & 1 & Silikalit-1 \\
Mehdipourghazi & 5 & 1 & MFI \\
& 50 & 1 & MFI \\
Chelsey Anderson & 20 & 1 & Silikalit-1 \\
\hline
\end{tabular}

Penelitian yang dilakukan oleh Lew $d k k$ yang berhasil mensitesis zeolit dengan perbandingan rasio $\mathrm{Si} / \mathrm{TPABr} \quad 3: 1$ [23] dan penelitian yang dilakukan oleh Mehdipourghazi dkk yang berhasil mensintesis zeolit tipe MFI dengan perbandingan Si/TPABr 5:1 dan 50:1 [24] serta penelitian yang dilakukan oleh Anderson dkk yang telah berhasil mensintesis zeolit silikalit-1 dengan perbandingan Si/TPABr 20:1 [22]. Pada penelitian ini perbandingan rasio $\mathrm{Si} / \mathrm{TPABr}$ untuk mensintesis zeolit silikalit-1 yaitu 1,3:1. Pola difraktogram yang diperoleh juga sesuai dengan pola difraktogram standar untuk zeolit silikalit-1 yang diperoleh dari database [25]. Difratogram memperlihatkan puncak-puncak yang tajam dan pemisahan yang baik. Hal ini menunjukkan bahwa zeolit silikalit-1 hasil sintesis mempunyai kristalinitas yang cukup tinggi dan menunjukkan tidak adanya fasa kristalin lain dalam zeolit silikalit-1 hasil sensitesis [26]. Puncak difraksi juga dapat memperkirakan ukuran kristal dengan menggunakan metode Schrerrer yaitu, jika puncak difraksi yang dihasilkan semakin lebar maka ukuran kristal semakin kecil dan jika puncak difraksi yang dihasilkan mendekati seperti garis vertical maka Kristal memiliki ukuran yang besar [27]. Ukuran kristal zeolit silikalit-1 dapat dihitung dengan persamaan Schrerrer dan untuk zeolit silikalit-1 hasil sintesis memiliki ukuran kristal sebesar 15,28 nm. Pada Gambar 3 dapat dilihat bahwa difraksi yang dihasilkan mendekati seperti garis vertikal yang sehingga zeolit silikalit1 hasil sintesis diperkirakan mempunyai ukuran kristal yang besar.

\section{Hasil Analisis Zeolit dengan FT-IR}

Penggunaan spektroskopi FT-IR bertujuan untuk mengetahui gugus fungsional suatu senyawa. Analisis FT-IR dilakukan pada rentang bilangan 400-3500 $\mathrm{cm}^{-1}$. Pada zeolit silikalit-1 
hasil sintesis terdapat beberapa vibrasi gugus seperti yang ditunjukkan oleh Gambar 4.

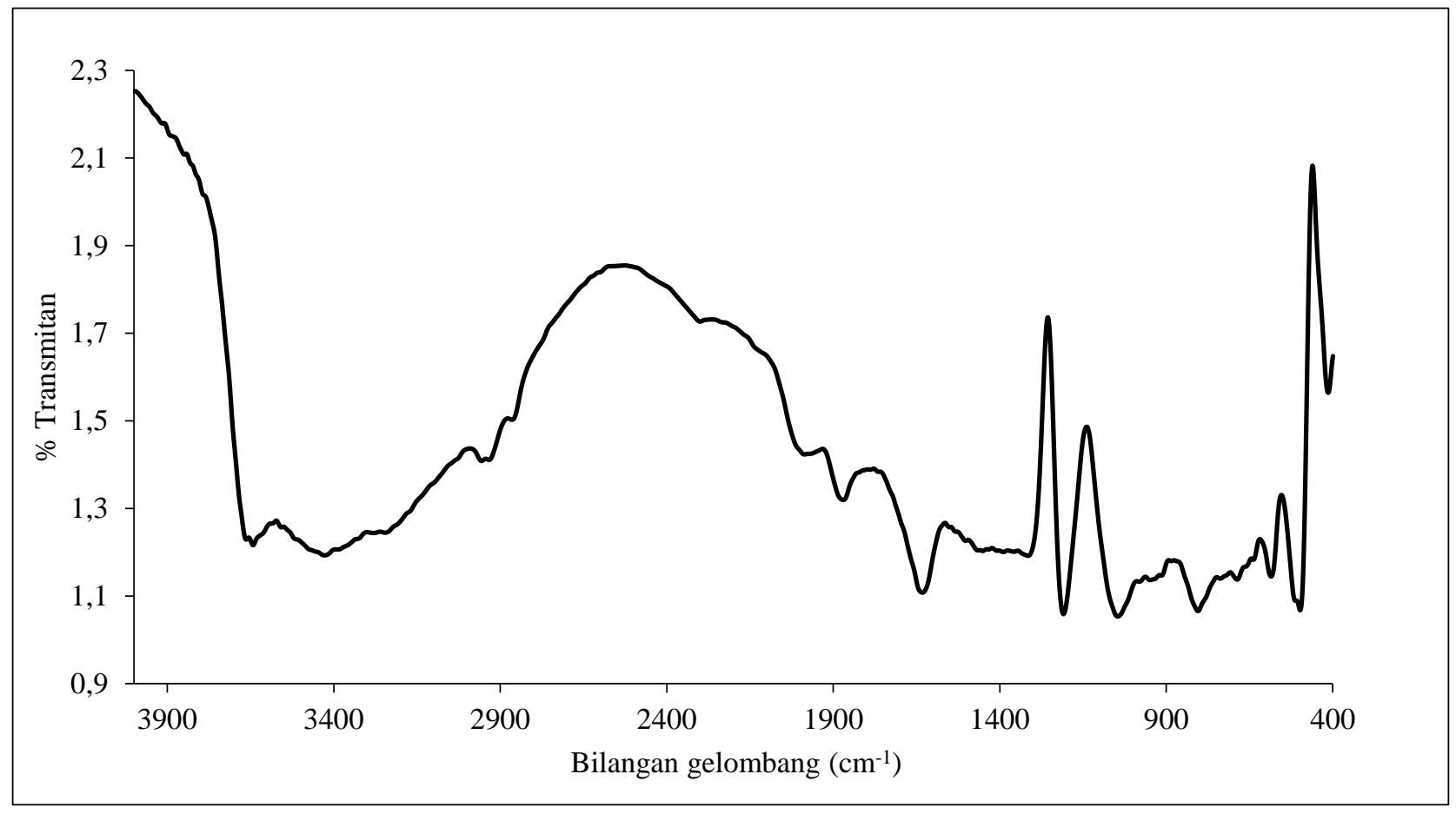

Gambar 2. Spektra FT-IR zeolit silikalit-1 hasil sintesis

Dari Gambar 4 diperoleh beberapa gugus yang dapat dilihat pada Tabel 3.

Tabel 2. Spektrum hasil FT-IR zeolit silikalit-1

\begin{tabular}{ccc}
\hline $\begin{array}{c}\text { Bilangan } \\
\text { gelombang }\left(\mathrm{cm}^{-1}\right)\end{array}$ & $\begin{array}{c}\text { Bilangan } \\
\text { gelombang } \\
\text { referensi }\left(\mathrm{cm}^{-1}\right)\end{array}$ & Gugus Fungsi \\
\hline 497,580 & $450-500$ & Si-O \\
584,853 & $550-600$ & D5R Pentasil \\
804,483 & $800-850$ & Si-O-T \\
1045.880 & $1000-1100$ & Si-O-T \\
1208,418 & $1107-1225$ & Si-O-T \\
\hline
\end{tabular}

Pola serapan dari silika hasil sintesis pada Gambar 3 menunjukkan bahwa serapan dengan pita lebar pada daerah bilangan gelombang $497,580 \mathrm{~cm}^{-1}$ merupakan pita serapan dari vibrasi gugus Si-O. Pita serapan di daerah $584,853 \mathrm{~cm}^{-1}$ merupakan pita serapan dari vibrasi tekuk D5R pentasil. Serapan pada bilangan gelombang $804,483 \mathrm{~cm}^{-1}$ menunjukkan adanya vibrasi ulur SiO-T, pita serapan pada $1045,880 \mathrm{~cm}^{-1}$ menunjukan adanya vibrasi ulur Si-O-T, dan pada pita serapan $1208,418 \mathrm{~cm}^{-1}$ menunjukan vibrasi tekuk Si-O-T [28].

\section{Hasil Analisis Zeolit dengan SEM}

Karakterisasi dengan menggunakan SEM bertujuan untuk mengetahui morfologi dari zeolit silikalit-1 yang terbentuk. Pencitraan dengan menggunakan SEM pada zeolit silikalit-1 dilakukan sampai pembesaran $2000 \times$ pada $10 \mu \mathrm{m}$ dengan tegangan $15 \mathrm{kV}$. Pada pembesaran sampai 2000× memperlihatkan bentuk kristal yang menyerupai bola-bola kecil yang mana setiap bentuk kristal satu dengan yang lainnya saling bertumpuk sehingga terlihat seperti gumpalan seperti yang ditunjukkan pada Gambar 5.

Pencitraan zeolit silikalit-1 pada pembesaran $2000 \times$ (a) hampir sama dengan hasil SEM pada penelitian sebelumnya yang dilakukan oleh Jia Hua dan Yu Han [29] dengan waktu inkubasi $12 \mathrm{jam}$ pada suhu $80^{\circ} \mathrm{C}$ diikuti dengan waktu inkubasi 4 jam pada suhu $120^{\circ} \mathrm{C}$. Namun pencitraan yang dilakukan pada pembesaran sampai 200× (b) terlihat kristal heksagonal. Pencitraan serupa ditunjukan oleh penelitian yang dilakukan Anderson $d k k$, dengan waktu inkubasi 72 jam pada suhu $150^{\circ} \mathrm{C}$ [22]. Pebedaan hasil yang diperoleh disebabkan oleh lamanya waktu inkubasi pada sintesis zeolit silikalit-1. Pada penelitian ini waktu inkubasi untuk sintesis zeolit silikalit-1 adalah 24 jam pada suhu $180^{\circ} \mathrm{C}$, sehingga kemungkinan zeolit silikalit-1 belum sepenuhnya terbentuk dikarenakan waktu inkubasi yang kurang lama [22]. 

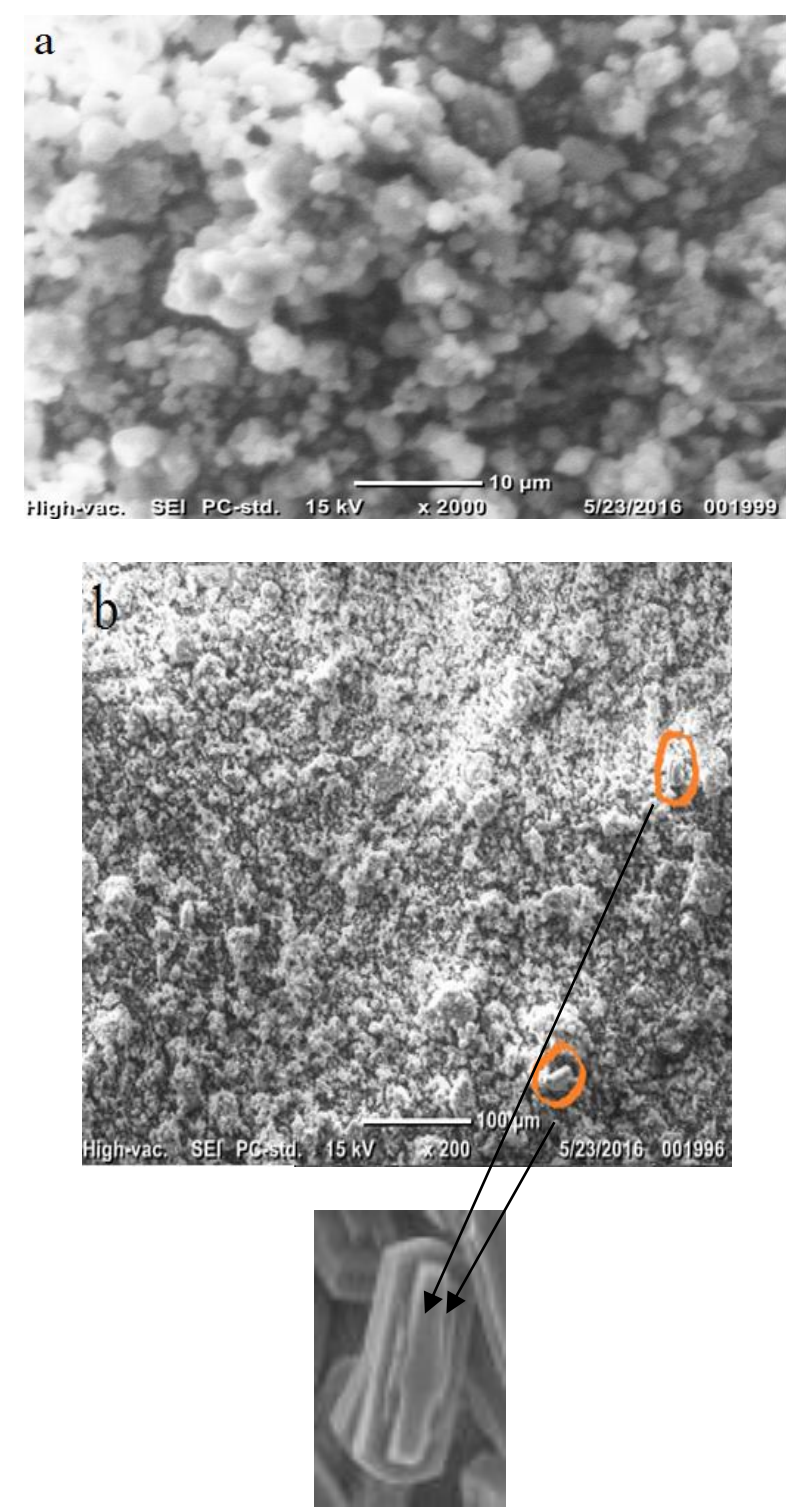

Gambar 3. Morfologi zeolit silikalit-1(a) pembesaran $2000 \times$, (b) pembesaran $200 \times$ [22]

\section{SIMPULAN}

Dari hasil penelitian ini dapat ditarik kesimpulan sebagai berikut:

1. Silika dapat diisolasi dari limbah tongkol jagung dengan persentasi kemurnian sebesar $50,1 \%$,

2. Silika hasil isolasi dari limbah tongkol jagung mempunyai fasa amorf yang telah dikonfirmasi dengan hasil XRD dan pita serapan yang muncul pada spektra silika hasil sintesis adalah gugus silanol $(\mathrm{Si}-\mathrm{OH})$ dan gugus siloksan $(\mathrm{Si}-$ $\mathrm{O}-\mathrm{Si}$ ),

3. Silika hasil isolasi dari limbah tongkol jagung dapat dijadikan sebagai sumber silika untuk sintesis zeolit silikalit-1 yang telah dikonfirmasi dengan hasil karakterisasi XRD dan FT-IR yang menunjukan puncak khas zeolit silikalit-1.
4. Morfologi zeolit silikalit-1 yang ditunjukan oleh hasil karakterisasi SEM menunjukan bahwa Kristal heksagonal zeolit silikalit-1 belum sepenuhnya terbentuk.

\section{UCAPAN TERIMA KASIH}

Penulis mengucapkan terima kasih kepada Lembaga Ilmu Pengetahuan Indonesia (LIPI) Serpong atas analisis meyode $X$-Ray fluorescence (XRF); Laboratorium Instrumen Kimia FST UIN SGD Bandung atas diskusi interpretasi Fourier Transform Infra Red (FTIR); Laboratorium Fisika FST UIN SGD Bandung atas diskusi SEM-EDX; Laboratorium Pusat Survei Geologi (PSG) dan Pusat Penelitian Bahan Tambang Teknik Mineral Batubara (PUSLITBANG TekMIRA) atas diskusi metode $X$-Ray Diffraction (XRD).

\section{REFERENSI}

[1] Sri Haryanti, "Jumlah dan distribusi stomata pada daun beberapa spesies tumbuhan dikotil dan monokotil," Buletin Anatomi dan Fisiologi, vol. 18, 2010.

[2] Luana Erviana, "Isolasi Silika Dari Tongkol Jagung," Surabaya, 2013.

[3] Hyunjung Lee and Prabir K Dutta, "Synthesis of Free-Standing Chabazite-Type Film," Microporous and Mesoporous Materials, pp. 151-159, 1999.

[4] Yoshiaki Goto, "Synthesis of Clinoptilolite," American Mineralogist, pp. 330-332, 1977.

[5] S Ueda, M Nishimura, and M Koizumi, "Synthesis of Offretite-Erionite Type Zeolite from Solution Phase," pp. 105-110, 1985.

[6] Tae Jin Kim, Seung Wha Ahn, and Suk Bong Hong, "Synthesis of Zeolite Ferrierite in the Absence of Inorganic Cation," Microporous Materials, pp. 35-40, 1996.

[7] Shervin Khodabandeh and Mark E Davis, "Synthesis of a heulandite-type zeolite by hydrothermal conversion of zeolite P1," pp. 105-110, 1996.

[8] Pramod K Bajpai, "Synthesis of Mordenite Type Zeolite," pp. 2-8, 1986.

[9] D Kusnida and M K Adisaputra, Mineral Philipsite. Bandung: Pusat Penelitian dan Pengembangan Geologi dan Kelautan, 2009.

[10] Antonis Zorpas and Vassilis J Ingerzakis, "NATURAL ZEOLITES: Industrial and Enviromental Application," HANDBOOK OF 
ZEOLITES: $\quad$ STRUCTURE,PROPERTIES AND APPLICATIONS, pp. 23-33, 2009.

[11] Takaaki Wajima, Kazuhara Yoshizuka, Takashi Hirai, and Yasuyuki Ikegami, "Synthesis of Zeolite X from Waste Sandstone Cake Using Alkali Fusion Method," Materials Transactions, vol. 49, no. 3, pp. 612-618, 2008.

[12] Gustavo Garcia, Edgar Cardenas, Saul Cabrera, Jonas Hedlund, and Johanne Mouzon, "Synthesis of Zeolite Y from diatomite as silica source," Microporouse and Mesoporouse Materials, pp. 29-37, 2016.

[13] W Panpa and S Jinawath, "Synthesis of ZSM5 Zeolite and Silicalite from rice husk ash," pp. 389-394, 2009.

[14] Yi-Hung Chen and Neng-Chou Shang, "The Application Of zeolites in Ozonation Processes For The Enhanced Removal Of Organic Pollutant from Aqueous Solution," HANDBOOK OF ZEOLITES: STRUCTURE, PROPERTIES AND APPLICATIONS, pp. 363-365, 2009.

[15] Karna Nicole Barquist, "Synthesis and enviromental adsorption applications of functionalized zeolite and iron oxide/ zeolite composites," pp. 13-28, 2009.

[16] Vineet Vaibhav, U Vijayalakshmi, and S Mohana Roopan, "Agricultural Waste as a Source for The Production of Silica Nanoparticles," Spectrochemica Acta Part A: Molecular and Biomecular Spectroscopy, 2014.

[17] Palanivel Velmurugan et al., "Extraction, characterization, and catalytic potential of amorphous silica from corn cobs by sol-gel method," Journal of Industrial and Engineering Chemistry, p. 6, 2015.

[18] Mahwish Saleem, Masooma Rustam, Hassan Javed Naqvi, Sidra Jabeen, and Amna Akhtar, "Synthesis Of Precipitated Silica From Corn Cobs By Using Organic Acids," Sci.Int., pp. 265-269, 2014.

[19] Nuwair, "kajian Impedansi dan Kapasitasi Listrik Pada Membran Telur Ayam Ras," Skripsi. Fakultas Matematika dan Ilmu Pengetahuan Alam, 2009.

[20] World Health Organization, "Crystalline silica, quartz," National Institute of Occupational Safety and Health dan World
Health Organization, Geneva, vol. 92, pp. 1020-6167, 2000.

[21] Umeda J, Imai $H$, and Kondoh $K$, "Polysaccharide Hydrolysis and Metallic Impurities Removal Behavior of Rice Husk in Citrit Acid Leaching Treatment," Transactiobs of JWRI, vol. 38, pp. 13-18, 2009.

[22] Chelsey Anderson, Nina Bass, and Amanda Clark, "Synthesis Of Silicalite-1 Aggregates," 2011.

[23] Maulana Yusuf, Dede Suhendar, and Eko Prabowo Hadisantoso, "Studi Karakterisasi Silika Gel Hasil Sintesis Dari Abu Ampas Tebu Dengan Variasi Konsentrasi Asam Klorida," pp. 16-28, 2014.

[24] Rasy Dwi Mujiyanti, Nuryono, and Eko Sri Kunarti, "Sintesis dan Karakterisasi Silika Gel Abu Sekam Padi yang Diimobilisasi dengan 3-(Trimetoksisilil)-1-Propantiol," Sains dan Terapan Kimia, pp. 150-167, 2010.

[25] Jaehong Shim, Palanivel Velmurugan, and Byung-Taek Oh, "Extraction and physical characterization of amorphous silica made from corn cobs ash at variable $\mathrm{pH}$ condisition via sol-gel processing," Journal of Industrial and Engineering Chemisrty, pp. 249-253, 2015.

[26] Cristopher M Lew, Zijian Li, Stacey I Zones, Minwei Sun, and Yushan Yan, "Control of size and yield of pure-silica-zeolite MFI nanocrystals by addition of methylene blue to the synthesis solution," Microporous and Mesoporous Materials, pp. 10-14, 2007.

[27] Mohsen Mehdipourghazia, Ahmad Moheb, and Hossein Kazemian, "Incorporation of boron into nano-size MFI zeolite structure using a novel microwave-assisted two-stage varying temperatures hydrothermal synthesis," Microporous and Mesoporous Materials, pp. 18-24, 2010.

[28] MFI: Silicalite-1. Synthesis Commission of Internasional Zeolit Association. [Online]. http://www.izaonline.org/synthesis/default.htm

[29] Yusri S, Sintesis dan Karakterisasi Zeolit ZSM-5 Mesopori Dengan Secondary Template dan Studi Awal Katalisis Oksidasi Metana. Jakarta: FMIPA UI, 2012. 